\title{
Progress in the application of hydrogen fuel cells
}

\author{
Xiaotong Zhang ${ }^{1 *}$, Fangqin $\mathrm{Li}^{1}$, Jian xing Ren ${ }^{1}$, Haijun Feng ${ }^{1}$, Chuang Ma1, Xin Hou ${ }^{1}$, \\ ${ }^{1}$ School of Energy and Mechanical Engineering, Shanghai University of Electric Power, Shanghai 200090, China
}

\begin{abstract}
Hydrogen fuel cell is a clean, efficient and pollution-free electrochemical power generation device, which has received widespread attention at home and abroad in recent years. The paper introduces the working principle and advantages of hydrogen fuel cells. The research and development progress of hydrogen fuel cells in electrolyte membrane, electrode, fuel and system structure are elaborated in detail. The hydrogen fuel cells at home and abroad are distributed in distributed power plants. Recent advances in applications for electric vehicles, military and mobile power. With the development of battery materials, improvement of preparation technology and reduction of production costs, this field will have broad market prospects.
\end{abstract}

\section{Introduction}

With the rapid development of the global economy, the continuous development and use of the three fossil energy sources, the shortage of energy reserves and environmental pollution have become increasingly prominent. The PM2.5 is seriously exceeded, and the continuous smog weather is a serious warning to the whole society. It has made people's development and utilization of green energy hydrogen energy and the development of new power plant fuel cells show great appeal ${ }^{[1]}$. A fuel cell is a highly efficient, clean power plant that converts the chemical energy stored in fuel and oxidant directly into electrical energy. Its energy is not limited by the Kono cycle, and the energy conversion rate can be as high as $90 \%$. It is $2-3$ times the actual use rate of the internal combustion engine. Zero pollution to the environment is the first clean and efficient power generation technology in the 21st century. Hydrogen fuel cells have become the focus of domestic and foreign companies, mainly due to high energy conversion efficiency, low clean pollution, no vibration, low noise, environmental friendliness and high reliability, so that hydrogen fuel cells have a wide market ${ }^{[2]}$.

\section{Classification of hydrogen fuel cells}

There are many types of fuel cells, and the classification methods are different. The commonly used classification methods are classified according to the electrolyte properties and operating temperatures of the fuel cell. Fuel cells include proton exchange membrane fuel cells, phosphoric acid fuel cells, solid oxide fuel cells, alkaline fuel cells, and molten carbonate fuels. Batteries, etc. ${ }^{[3]}$ Five commonly used different electrolyte fuel cells; AFC and PEMFC are generally classified as low temperature fuels, PAFCs are medium temperature fuels, and MCFCs and SOFCs are high temperature fuel cells when distinguished according to different operating temperature ranges. See Table $1^{[4]}$.

Table 1 Fuel cell classification

\begin{tabular}{|ccccc|}
\hline Types & Electrolyte & Conducted ion & $\begin{array}{c}\text { Operating } \\
\text { temperature } /{ }^{\circ} \mathbf{C}\end{array}$ & fuel \\
\hline PEMFC & $\begin{array}{c}\text { Perfluoro sulfonic acid } \\
\text { membrane }\end{array}$ & $\mathrm{H}^{+}$ & $\begin{array}{c}\text { Room } \\
\text { temperature-100 }\end{array}$ & $\begin{array}{c}\text { Hydrogen, Reforming } \\
\text { gas }\end{array}$ \\
\hline $\mathrm{SOFC}$ & Zirconia & $\mathrm{O}^{2-}$ & $900-1000$ & Purifying gas, natural gas \\
\hline PAFC & $\mathrm{H}_{3} \mathrm{PO}_{4}$ & $\mathrm{H}^{+}$ & $100-200$ & Reforming gas \\
\hline MCFC & $(\mathrm{Li}, \mathrm{K}) \mathrm{CO}_{3}$ & $\mathrm{CO}^{2-}$ & $650-700$ & $\begin{array}{c}\text { Purifying gas, natural } \\
\text { gas, Reforming gas }\end{array}$ \\
\hline AFC & $\mathrm{KOH}$ & $\mathrm{OH}^{-}$ & $50-200$ & Reforming gas \\
\hline DMFC & $\begin{array}{c}\text { Perfluoro sulfonic acid } \\
\text { membrane }\end{array}$ & $\mathrm{H}^{+}$ & $650-700$ & $\begin{array}{c}\text { Purifying gas, natural } \\
\text { gas, Reforming gas }\end{array}$ \\
\hline
\end{tabular}




\section{Hydrogen fuel cell application}

\subsection{Application in decentralized power stations}

Large-scale power stations, whether nuclear, thermal or hydropower, send the emitted electricity to the grid and then to the user. However, due to the different load of each user, the voltage is unstable or power is cut off. In addition, due to the traditional thermal power generation, a large amount of fossil energy is consumed and a large amount of toxic and harmful wastes are discharged into the environment. The use of hydrogen fuel for power generation, its energy conversion efficiency can reach $60 \%$ to $80 \%$, even $200 \%$ higher than the traditional firepower point. The noise is small, the pollution is small, the device can be large or small, very flexible, so the application range is very wide.

As early as 1997, the PlugPower Proton Exchange Membrane Fuel Cell Company successfully developed the world's first gasoline-fueled PEMFC generator set. In 2002, the GEHomeGen7000 PEMFC power station with a capacity of $7 \mathrm{~kW}$ was supplied, enough to provide a household's electricity demand. Canada's Ballard Company developed a PEMFC power generation system with a capacity of $250 \mathrm{~kW}$ in 1999 , which can provide 50 to 60 homes. The PEMFC power generation system uses a distributed system design, and even in the case of a few battery stack failures, the entire power generation system can still operate normally ${ }^{[5]}$.

\subsection{Application in hydrogen fuel cell vehicles}

The use of hydrogen fuel cells in automobiles is currently a research hotspot for fuel cells. Many world-renowned automobile companies have introduced hydrogen-fueled vehicles. It is expected that the use of fuel cells will reduce air pollution and reduce the dependence of modern society on oil. Since the hydrogen fuel cell vehicle emits only water, it is far beyond the oil-powered internal combustion engine model as the ultimate goal of the future car. Therefore, hydrogen fuel cell vehicles have gained worldwide recognition.

\subsection{Domestic hydrogen fuel cell vehicle application}

China's fuel cell vehicle technology research and development under the support of the national "863" plan electric vehicle key technology major science and technology projects, made important progress, basically mastered the core technology of the vehicle, power system and key components and built fuel on this basis The battery vehicle power system technology platform forms a supporting R\&D system for key components such as fuel cell engines, drive motors, power batteries, hydrogen storage and hydrogen supply systems.

In 2008, China's self-developed Volkswagen Passat model, through the restructuring and integration of the latest generation of fuel cell car power system platform hydrogen fuel cell car ${ }^{[6]}$ held a ceremony at the New Energy Automobile Engineering Center of Tongji University, and put into operation during the Olympic Games. These 20 fuel cell vehicles use hydrogen as an energy source to generate water through the oxidation reaction, thus realizing zero pollution.

The use of hydrogen fuel cell vehicles in the Beijing Olympic Games and the Shanghai World Expo has demonstrated China's strength and progress in the development and application of hydrogen fuel cell vehicles. However, the research level of hydrogen fuel cells in China is still far from that of some developed countries in Europe and America. The performance of hydrogen fuel cell cars in China is more than 200 kilograms, and the price is more than 5 times. Moreover, the hydrogen fuel cell vehicle is still in the stage of technical verification and specific assessment test.

\subsection{Application of foreign hydrogen fuel cell vehicles}

GM and DaimlerChrysler collaborate on fuel cell vehicles. Followed by Toyota and Honda Motor Co. of Japan. Companies are constantly introducing new prototypes, and technology is getting closer to practical use. In 2000, General Motors exhibited at the Sydney Olympics as a pilot for the marathon. He was a Hydrogen-fueled HydroGen1 fuel cell sedan. In 2004, General Motors of the United States conducted a long-distance marathon test across the European continent for its improved fuel cell vehicle fueled by compressed hydrogen ${ }^{[7]}$.

The British government will vigorously develop hydrogen fuel cell vehicles. It plans to maintain 1.6 million hydrogen fuel cell vehicles in the UK by 2030 and bring its market share to $30 \%$ to $50 \%$ by 2050 . The government will implement local production of hydrogen fuel cell vehicles from 2015, and develop related technologies on its own. In addition, hydrogen fuel supply stations will be built. At present, from this year on, Hyundai, Toyota, DaimlerChrysler, Honda and other companies will launch hydrogen energy vehicles in the Dutch market. The Dutch government said it will take the lead in pushing the development of global hydrogen energy vehicles to a new stage ${ }^{[8]}$

After long-term, steady and steady government and large-scale multinational companies, the reliability and environmental adaptability of foreign fuel cell vehicle products have made major breakthroughs. The demonstration operation has been deepened and the advanced fuels for commercialization demonstrations have been launched. Battery vehicles, fuel cell vehicles enter the technology and market demonstration stage ${ }^{[8]}$.

\subsection{Application in mobile power}

In the past ten years, portable electronic products such as mobile phones, notebook computers, and digital cameras have become more and more popular, and their functions have become increasingly complex and energy consumption has increased. Therefore, batteries are 
required to have high energy density and long use time. However, the current lithium-ion batteries on the market can no longer meet the increasingly demanding needs of people. According to reports, the Motorola company in the United States uses PEMFC as the battery of the mobile phone, which makes the continuous standby time up to $1000 \mathrm{~h}$, and the talk time can reach $100 \mathrm{~h}$ after a sufficient fuel. Japan's Toshiba's PEMFC power supply for portable electronic devices has a power range of tens of watts to hundreds of watts, which is sufficient for field power supply, emergency power supply, and high reliability and high stability power supply ${ }^{[9]}$.

In addition, hydrogen fuel cells are also used in portable chargers. For example, Horizn recently introduced a portable proton exchange membrane fuel cell kit called MiniPak, which uses fuel produced by electrolyzed water and then stored to carry fuel. It takes only a few milliliters of water for cameras, mobile phones and The GPS device provides ten hours of power. The entire battery pack weighs only $150 \mathrm{~g}$ and is very lightweight and can be carried around. The charger can be used with any device with a USB interface. It does not require any water, even if the sewage can work normally, so you don't have to worry about the phone. Electric ${ }^{[10]}$.

\section{Conclusion}

The development and commercialization of hydrogen fuel cells is a necessary means to achieve energy conservation and environmental protection. The practicality of hydrogen fuel cells has been recognized worldwide. Although there are still some problems in the development and utilization of hydrogen fuel cells, such as electrode materials, manufacturing costs, catalysts, as a true zero-polluting clean energy source. The use of hydrogen fuel cells worldwide is increasing rapidly. With the cost reduction and the comprehensive development of hydrogen energy technology, the problems in the commercialization of fuel cells will be gradually solved. I believe that hydrogen fuel cells will be used in the near future. It will be applied to all aspects of life, and people will no longer worry about fossil energy and environmental issues.

\section{References}

1. Pan X, Lin R, Xin L I, et al. Research Development and Commercialization Advances of Hydrogen Energy and Fuel Cell[J]. Science \& Technology Review, 2011, 29(27):73-79.

2. Shen Q, Hou M, Yan $\mathrm{X}$, et al. The voltage characteristics of proton exchange membrane fuel cell (PEMFC) under steady and transient states[J]. J Power Sources, 2008, 179(1):292-296.

3. Yu J, Yi B, Xing D, et al. Degradation mechanism of polystyrene sulfonic acid membrane and application of its composite membranes in fuel cells[J]. Phys Chem Chem Phys, 2003, 5(3):611-615.

4. Feng $\mathrm{C} \mathrm{H}$, Li F B, Liu H Y, et al. A dual-chamber microbial fuel cell with conductive film-modified anode and cathode and its application for the neutral electro-Fenton process[J]. Electrochemica Acta, 2010, 55(6):2048-2054.

5. Fu Q, Li W X, Yao Y, et al. Interface-Confined Ferrous Centers for Catalytic Oxidation[J]. Science, 2010, 328(5982):1141-1144.

6. Ishigame A. Preface to Spcial Issue on Application and Control Technology of Battery Energy Storage for Power Systems. [J]. Ieej Transactions on Power \& Energy, 2017, 137(10):643-643.

7. Lee D, Bae J. Visualization of flooding in a single cell and stacks by using a newly-designed transparent PEMFC[J]. Int J Hydrogen Energ, 2012, 37(1):422-435.

8. Cozzolino R, Cicconardi S P, Galloni E, et al. Theoretical and experimental investigations on thermal management of a PEMFC stack[J]. Int J Hydrogen Energ, 2011, 36(13):8030-8037.

9. Jiang Lijun, Zhang Xiangjun, Liu Xiaopeng, et al. Research Progress of New Energy Materials[J]. Chinese Materials Progress, 2009, 28(Z1): 50-56.

10. Wang Ziwei. Research progress of proton exchange membrane fuel cells and exchange membranes [J]. Henan Chemical Industry, 2018 